World Lumen Congress 2021 | May 26-30, 2021 | Iasi, Romania

\title{
Value Orientations in Education System: Approach, Interpretation, and Formation
}

\author{
Diana ANTOCI
}

https://doi.org/10.18662/wlc2021/02

How to cite: Antoci, D. (2021). Value Orientations in Education System: Approach, Interpretation, and Formation. In A. Sandu (vol. ed.), Lumen Proceedings: Vol. 17 World Lumen Congress 2021 (pp. 06-25). Iasi, Romania: LUMEN Publishing House. https://doi.org/10.18662/wlc2021/02 


\title{
Value Orientations in Education System: Approach, Interpretation, and Formation
}

\author{
Diana ANTOCI ${ }^{1}$
}

Abstract

The implemented theoretical study has revealed various scientific positions aimed at: interpreting the concepts of value and value orientation; finding controversial positions and affinities in the use of "value" and "value orientation" concepts; identifying ambiguous positions on structural elements of value orientation and value formation mechanism.

The purpose of undertaken research was theoretical, experimental and methodological in nature, outlining formation of value orientations in adolescence and youth ages. The developed definitions and determined structural components of value orientations allowed initiation of an experimental investigation of value orientations in adolescents and young people through which interrelation between the constitutive components of value orientation was confirmed, the specifics of values in adolescents and young people was emphasized. Outlining the specifics of value orientation structure led to identification of criteria, indicators and descriptors and to development and validation of a Questionnaire for Value Orientation Assessment.

The results of experimental study laid the basis for development and recognition of a Pedagogical Model for formation of value orientations in adolescents and young people. The previously identified mechanism for formation of values and functioning of value orientations was transposed into the nucleus of the Pedagogical Model, which included the following components: behaviour, emotional states, attitudes, convictions, and values.

In order to identify the methodology for forming value orientations in the formal, informal and nonformal educational environment, the principles of humanistic, constructivist and cognitivist education, strategies, conditions were highlighted, which ensure a dynamic progress in general development of the personality, implicitly of value orientations, and which is taken into account in framework of a formative experiment. The data obtained from the validation of the developed Pedagogical Model confirmed its effectiveness and proved that it was a multidimensional one, which could be of great benefit to specialists in the field of Education Sciences and teachers from schools and higher educational institutions.

Keywords: value, value orientations, adolescents, young people, Pedagogical model, behaviours, affective states, attitudes, convictions, values.

1 Associate Professor, PhD, Chair of Psycho-pedagogy and Preschool Education, Tiraspol State University, Chisinau, Republic of Moldova, e-mail address: antoci.diana@,ust.md 


\section{Introduction}

Currently, the educational process in schools and higher level institutions is well structured and systematized, based on various scientific positions, which determine the directions of action related to the specifics and particularities of training, the principles applicable to the entire teachinglearning-assessment process, educational policy documents, etc. At present, the instructive-educational process focuses on competences and values.

Regarding competencies, we find multiple scientific research papers that conceptualize, define the notion of competences, highlight their structural components, classify them, demonstrate the relationship with the structural elements of the personality, identify the defining factors in formation and modelling of competencies, etc. On the other hand, we note the inclusion of values in the structural composition of competencies. In the Glossary of Reference Framework of Competences for Democratic Culture published by the Council of Europe (Glossary CRCCD, 2018), the values are presented as "general convictions about desirable goals" which have to be achieved by individuals. According to generalization of CRCCD (Council of Europe, 2018 , p. 9) 20 competencies are divided into 4 categories: values, attitudes, abilities and knowledge. In the consecutive order of the elements, the values are placed at the top. As reported by the authors of CRCCD (Council of Europe, 2018), democratic competence mobilizes and implements relevant psychological resources such as: values, attitudes, abilities, knowledge and/or understanding as a support in manifesting appropriate reactions to "respond adequately and effectively to the requirements, challenges and opportunities presented by democratic situations". Intercultural competence is described as "the capacity to mobilize and implement relevant psychological resources to respond adequately and effectively to the requirements, challenges and opportunities presented by intercultural situation". In respect to this definition, it is assumed that a certain level of competence development exists and such competence is focused on: knowledge, abilities / capacities and attitudes. Depending on the subject's experience, his/her intensity of engagement in various activities, involvement of the social environment in the formation of the personality as a whole promotes and strengthens the development of skills. Within the personality, there is a system of competencies that consists of a number of competencies organized in a hierarchical structure specific to each person.

The educational outputs are precisely set out in art. 11 of the Education Code of the Republic of Moldova (Parliament of the Republic of Moldova, 2014) which in paragraph (1) mentions "the formation of an integrity and the development of a system of skills that includes knowledge, 
skills, attitudes and values that allow the active participation of individuals in social and economic life" and, accordingly, paragraph (2) lists the key competencies needed to be formed. Thus, the education mainly aims at establishing and developing a system of competences and values. However, these concepts require a separate approach and more detailed examination, with a view to highlight the peculiarities thereof. Also, the methodology for their establishment in the education and process needs to be determined.

From a theoretical perspective, the existence of a relationship between values and competencies is obvious; however, from an experimental viewpoint, it needs to be studied. Still, we cannot, by any means, include values in the structural composition of competencies. The question would be: what is the specific position of values in relation to competencies? One way of interpreting their relationship emphasizes the positioning of values at a higher level of than competences in the sphere of personality that monitors competencies, or, the latter are related to values. It is essential to acknowledge that the concept of value cannot be equalled to competence and cannot be part of the internal structure of a competence.

Therefore, we find that values are a central point in educational policy documents which guide the entire education system, but it is necessary that such policies comprise scientific data that substantiate the concept of values, value orientations, identify the structural composition and the mechanism of values formation. The above-mentioned aspects are important from the perspective of the educational system and they need clarification: how we develop values in subjects within the framework of the instructive-educational process.

Finding the answer to this question is extremely important so as to avoid multiple pedagogical failures, to structure, systematize and streamline the entire educational process as related to educational policy documents.

\section{Scientific positions in the paradigm of value orientations}

The need to determine the structural contents of values and value orientation derives from the need to establish theoretical, methodological guidelines for developing a methodology for forming values and value orientations in subjects in general and within vocational, technical and university level educational institutions and within systems for informal education and lifelong learning entities, especially perennials ones desirable for the entire of humanity.

In the 19th and 20th centuries, values acquired a sense of absolute appreciation, the criterion of which goes beyond the boundaries of human 
activity. The values are also interpreted from the perspective of structural contents, functionality, intentionality. Moreover, a substantial contribution to the progress of this area of study was fulfilled by thinkers/theorists (?) of the field of philosophy: Adorno (2000), Andrei (1997), Dewey (1992), Horkheimer (2002), Vianu (1998) and so on.

The notion of value is a fundamental one. It is examined and explained from a philosophical perspective. Within such philosophical approach the origin, emergence, evolution and historical and socio-cultural of values are substantiated. The concept of value was a landmark in the research of scientists Andrei (1997), Cucoş (1995, 2000), Pâslaru (2006), Râmbu (1997), Silistraru (2006), Vianu (1998) etc. The analysis of their scientific views elucidates the common point that refers to the cognitive, volitional, affective sphere of the human and which represents the psychic aspect with wide functional application.

From a philosophical viewpoint, the concept of value was addressed by the Romanian scientist Petre Andrei in his paper "Philosophy of value" (1997). Andrei (1997) found the value as being a psychic phenomenon, a feeling accompanying a judgment, seeking to achieve its object in the form of a goal. However, the individual forms different values according to external circumstances or according to his/her mood. Andrei (1997) highlights a multitude and a range of values, which can be divided by certain criteria (validity, quality, subject, motives, object, psychic faculty, their scope), thus establishing a balanced hierarchy, a value scale.

Another Romanian scientist, Vianu (1998) examines values as objects of consciousness, which can be contained in acts of desire regardless of their link with certain things, i.e. with those specific supports of which were given the name of goods. However, the values also give an indication of the kind of specific support with which they can be connected. Not every value can be connected to any specific medium. While encompassing charity, consciousness is fully interpreted by the value of a human character or deed, i.e. by a personal value. In respect to an economic value, such as edibility, it is meant as a value which can only be connected to things, i.e., to a genuine value. Vianu (1998) mentions that it is not possible to include charity as the value of some goods, nor to perceive edibility as the value of some people. Although an individual gets some of his/her food through consumption of organic beings, he/she does not include them as persons, but as things. Human being perceives edible animals as a value of certain things. If a person conveys to animals reputed to be edible the value of persons, he/she ceases to allow them the genuine value of edibility. This is the case of the ascetics, who, by extending their personal sphere in the world to or close to the biological limit, refuse to use as food what for them no longer reflects a 
genuine value. The introductory case of ascetics or "vegetarians" of mystical vocation sheds light on the fact that the values comprise also an indication of the type of specific support intended to accompany a value (Vianu, 1998).

The issue of studying the personality value orientations is widely addressed by scientists in pedagogy and psychology including: Botnari (2014), Callo (2014), Kon (1989), Cucoş (1995, 2000), Macavei (2001), Maslow (2017), Mudrik (2011), Silistraru (2006, 2014), Pâslaru (2006) and others.

From a psychological perspective Karpushina et al. (2007) the notion of value is defined as an attitude of the subject towards various facts, events of life, object and subject and their recognition as important in life. The following values and spheres of life are being assessed by the authors: selfdevelopment; spiritual satisfaction; creativity; social contacts; personal prestige; good financial condition; skills; personal level of individuality; sphere of professional life; sphere of studies, education; sphere of family life; sphere of social life; sphere of entertainment; sphere of physical activity.

Voicu (2008) mentions that from a psychological viewpoint, values are elements of individuals' orientation in the outer world. They consist in decoding possible actions allowing for identifying potential gratifications, advantages generated by the scales of everyone's preferences, depending on individual motivations, needs and aspirations. From the sociological and anthropological perspective, the values are defined as being internal to the individual, different from one to another, but having a relevant social element, expressed and at the same time induced by the rules, habits and ideologies. The scientist concludes that, as in the case of beliefs, the values are mere individual perceptions of the collective values and beliefs peculiar to each culture and internalized by means of socialization.

According to C. Jung's position (Jung, 1931, cit. in Ewen, 2014), value orientations imply a behaviour that due to needs corresponds to instinctual behaviour. Convictions give rise to conscious motives, ideas impacting the entire life of a personality, shaping as well the values. Such components are infused with emotions.

Additionally, C. Jung (Jung, 1972, cit. in Ewen, 2014, p. 57) emphasizes that value orientations have the property of changing throughout the lives of individuals and expresses it as follows: values are especially likely to go through radical changes as one grows from the morning of youth, through the afternoon of middle age, with increasing religious needs, while material and sexual needs becoming less important.

Like C. Jung, E. Fromm (Fromm, 1947, cit. in Ewen, 2014, p. 124) considers that life must be meaningful and purposeful. So, each of us should have a "personal philosophy that sets our life values and goals, guides our 
behaviour and delineates our place in the world". That is to say, all this, according to E. Fromm, constitutes "a frame of orientation". The orientation content is incorporated in the value orientations that are manifested in the personality behaviours. E. Fromm claims that "we do not find any culture in which there does not exist [some] frame of orientation. Or any individual either" (Fromm, 1973, cit. in Ewen, 2014, p. 124). This thought is leading to the final idea that the value orientation of the personality is shaped in culture, society, being developed through transcendence in order to significantly impact on our environment.

Rogers (1977, cit. in Ewen, 2014) and Maslow (1968, cit. in Ewen, 2014) believes that later in life, the way starting from self-knowledge is fostered by various institutions and social groups. Many people internalize these external standards (including parental standards) and think that they are theirs, even if they might not fit our true needs and values of the body. Namely, through our desires or necessities for updating, self-knowledge or compliance with external requirements, we are causing changes in the value orientations system. The process of change can be outlined as a progressive or regressive spiral conditional on the personality only.

A. Maslow (Maslow, 1968, cit. in Ewen, 2014, p. 215) notes that social forces can help individuals cope with certain obstacles, express their meta-needs and discover the values they actually want to acquire.

Tomin (2017, pp. 59-64) states that values can have a simultaneous effect of grounds, resource, condition and interaction. Furthermore, the coexistence of the values projections of various cultures in the mind of a person determines the obstacles in selecting strategies of their relevant manifestation in terms of intercultural interaction.

Rybak (2018, pp. 11-23) believes that the value orientation system reflects a significant treatment of social reality by an individual consequently determining the motivation for the person's conduct, considerably impacting all aspects of own activity. This is an entire social and psychological occurrence, which describes the vector and content of person's activity, generating the global attitude of the person to the world, to a particular individual, assigning meaning and direction to points of view, behaviour, personal action. The value orientation system is multi-levelled in terms of structure. The values related to the ideals and life goals of an individual are situated on the top of it. Being a component of the personality structure, the value orientations illustrate the internal availability for carrying out certain activities in view of responding to some needs and satisfying some interests. They show the individual's conduct direction. Whereas the set of values collected by an individual during socialization is "translated" by society itself, studying the value orientation system of a personality who grows and 
develops in a particular culture is a very topical issue. In order to study the value orientations available in the modern society, it is required to clarify the nature and mechanisms of the ongoing processes.

The concept of value orientations has also been assessed with regard to society, history, culture, particular social groups and, especially, individuals. Though, the value orientation concept is more extensive compared to the concept of value, because it involves a value connection and value-oriented subject. In terms of structure, the value orientation system consists of several levels, with values in the top position.

\section{Conceptualizing the notions of value and value orientation}

Examining a multitude of approaches in the classification of values, we determined that it is impossible totally to disengage one type of value from another by content, because they intersect with each other (Antoci, 2018a). Thus, moral values are the component part of all values. For example, in the theoretical-experimental study of civic values in Moldovan students, we highlighted the following structural components of civic values: morality, patriotism, ethnicity, national, civic (Antoci, 2018b). It is important to mention that each of the highlighted components also involves focusing on the structural elements of other values such as ethics, aesthetics, etc. In the research conducted through the tool for the complex assessment of civic values we managed to determine the specifics of civic values in young people in rural and urban areas, the relationship of civic values with motivation for learning.

The same approach to studying certain types of values can be applied to other values in a similar way, based on any classification. Another approach in the research of values would be the structuralist one, namely, the one of establishing the mechanism of values formation and the main constitutive elements. The elements that contribute to the shaping of values determine the composition of the structural set of values and together with the latter make up the whole, which is called value orientations. The process of their functionality has been studied and described by us in detail in quantitative, qualitative and graphical form.

Therefore, generalizing the research results, we proposed a definition of value from the perspective of the internal specifics of the human being in terms of general and social principles and needs: value is a fundamental mental organization to establish direction, identify effective pathways to follow in certain circumstances, cognitively organized into points of view, for the acquisition of facts, ideas, phenomena, correlated with social requirements and ideals produced by them, which 
support decisions made in various situations / problems, by developing the most appropriate, adequate attitude, putting value on an object / action expressed by behaviours (Antoci, 2020).

Noting the presence of the methodological issue in formation of values in the field of education, we conceptualized the notion of "value" from the pedagogical and psychological perspective: value is the central point of positioning of the entire personality system constituting the transcendent, not final, output, of the educational process under the impact of the sociocultural environment which coordinates for a long period of time the cognitive, affective, volitional-motivational, behavioural spheres of the individual.

The identified contents and the developed definitions served as a benchmark for initiating the research that aimed to determine the functionality of the structural components within an established system.

\section{Experimental validation of the structural components of values}

The described theoretical position regarding the composition of the structural contents of the value orientation was subjected to experimental research. To achieve this objective, we applied a set of tools for evaluating each element of the value orientations. The obtained results allowed to determine the psycho-pedagogical particulars of the manifestation of the elements studied within each age stage; to highlight the dominant variables within the evaluated components. The data revealed the specifics of the progress in manifestation and development of each element of the value orientation. Therefore, the results were analysed from a statistical perspective and the correlation coefficients were obtained, which confirmed the medium and strong intensity relationship between the studied elements. Below the established correlations are presented (fig. 1). 


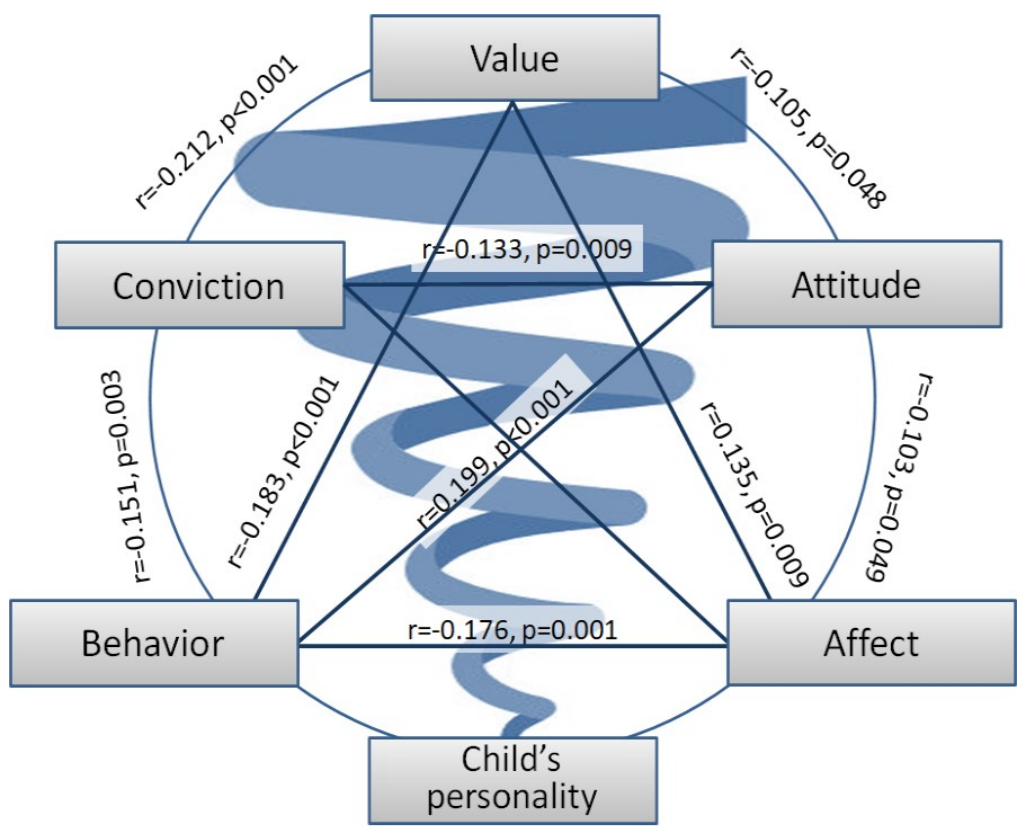

Figure 1. The established ratio between the structural components of value orientations

The established relationship between behaviour, emotional states, attitude, conviction and value confirms the hypothesis put forward regarding the existence of a significant relationship between the composing elements of the value orientation in the sphere of personality. The relationship established between all components indicates the functional mechanism of value orientations. The development of the constituent elements and the relationship between them occurs successively from childhood, the process being latent and spiral-like, which gradually encompasses all previously formed elements, laying the foundation for shaping the subsequent ones in consecutive order until reaching values. The values in their development reach the point of transcendence, which shows a dominant hierarchy, which allows for the monitoring of the entire personality.

Thus, the analysis of the theoretical-experimental study data allowed us to determine the particulars of the component manifestations of values orientations and values in adolescents and young people. Adolescence and youth are the decisive age in the formation of value orientations, which, in turn, are essential for the personality system and social inclusion. The values internalized in the process of personality formation serve as a standard for the subject, with which they constantly compare their interests, personal behaviour, etc. and plan their future. 
Focusing on the study, we find that values are the ones that monitor convictions, attitudes, affectivity and behaviour, which are closely related to each other and form a mechanism for functioning of value orientations. The concepts of value and value orientation cannot be used as synonyms, although they have multiple tangential areas.

\section{The questionnaire for the evaluation value orientations}

The implemented theoretical-experimental research highlighted the constitutive elements of value orientations, the system of significant relations between the structural components. The study conclusions have led to the development of an instrument allowing to evaluate both each of the elements of the entire system and the value orientations as a total. In this case, we made use of the structuralist approach. The procedure for developing the Questionnaire for assessing the value orientations of the personality focused on the psychometric requirements of psychodiagnosis and the strategies of deduction, induction and externalisation. In the development of the questionnaire, we observed the previously determined structure of value orientations. For each element we included three possible manifestations related to the specifics of values. The total number of statements was 120 . Their content was related to the specifics of values highlighted for evaluation.

All human beings have certain specific behaviours, qualities, traits, values, etc. In case of values, we can say that for a personality (if we refer to personality in its scientific complexity) they are present in a certain number within the value system. Most people with the same socio-cultural background have a number of values that are similar in quantity, but differ in quality. Values can be shared by all people, but different people have them in varying degrees that vary depending on how well known, aware, functional and close to the core of the personality they are. Based on the fact that each personality is unique and unrepeatable, we can say that the values are internalized in a unique, individualized form, which then influences the manifestations of value and have a personalized form. This is the essence of organizing and ranking values in a single system, with important and less important values.

In the view of M. Rokeach (1979, cit. in Hills, 2002) there are at most 36 values held by human beings, which have been examined from a broader and probably universal perspective. Concepts such as honesty and courage, peace and wisdom are recognized in all human cultures. On the other hand, Hofstede (1980, 2001, cit. in Hills, 2002), in a huge worldwide 
study, managed to find no more than five values that are universally held. Therefore, we find different opinions in respect to the number and variety of values, which form value orientations, in the sphere of personality.

The analysis of various scientific positions in philosophy, pedagogy, psychology allowed us to highlight a number of value orientations that are common to human beings. These are: morality, social recognition, material advantage, creation, personality development, health, professional development, family.

The degree of manifestation of each component indicates the complexity of value development in a subject and reflects the sincerity, the correctness of the evaluation made. The general characteristic of value orientations is described using 3 levels (high, medium, low). The established levels are general and applicable to the categories involved in the research, while the specificity of the levels results from the specificity of the categories of value orientations and their manifestations. The questionnaire for assessing value guidelines was validated in accordance with psychometric requirements.

\section{The value orientations formation model of adolescents and young people}

While acknowledging the theoretical and applied relevance of the study, it is worth noting that some aspects related to openness in pedagogy and educational psychology have not been subject to adequate research as related to the methodology of forming value orientations in adolescence and youth.

Examining the large number and the variety of scientific approaches to value orientations and value classifications, we established that it is impossible to set apart many types of values present in the personality value system. Based on the performed theoretical-experimental research, we can state that all values are in a relationship of different degrees of intensity each with the other, the values' structural components interrelate thus establishing various connections between value orientations in the sphere of personality. The study of civic value allowed us to come to the conclusion that civic values integrate selectively the partial content of moral, national, ethnic, patriotic and civic values, which interconnect at the same time establishing common grounds for a perfect personality [18]. The level of development of the contents of the value guidelines is directly related to the social environment of which it is part. 
Following the synthesis of the outcomes of the entire study, we believed it essential to capitalize on the data obtained in the development of the Value Orientations Formation Pedagogical Model of Adolescents and Young People (fig. 2).

The Pedagogical Model aims at forming value orientations in adolescents and young people. The formation of value orientations involves a set of contents consisting of behaviours, emotional states, attitudes, beliefs and values. Adolescence is considered as a decisive and sensitive phase for formation of personality. It is a period of development of numerous algorithms of intellectual activity, of obvious transformations in the fields of affectivity, the sensory-perceptual sphere, which are also decisive for social learning, cultural absorption, professional and personal design.

While determining the components of personality value orientations and analysing their contents, studying current educational practices, examining directives in educational policy documents we have highlighted the relevant principles for formation of value orientations of adolescents and young people in humanistic, constructivist and cognitivist paradigms. The observance of the highlighted principles guarantees the progress in the general development of the adolescents and young people, implicitly the value orientations formation in the personality system.

Humanism puts the human being in the centre of the universe. It is a complementary approach, necessary for education and it does not exclude the others. The principles of humanities education are: confidence in the human potential (learning to learn); emotional acceptance; participation and teamwork; cognitive processing; discovery through experience. The analysis of the positions of C. Rogers (Rogers, cit. in Pânişoară, 2019, p. 85) allows us to conclude that the principle of trust in human potential is significant when learning has meaning for the subject and is carried out voluntarily, through action. Therefore, participatory learning has a determining role, and the threat has a positive role in case of decrease in self-strength. Selfcriticism and self-assessment increase learning; thus, learning to learn is one of the essential objectives of humanities education. 


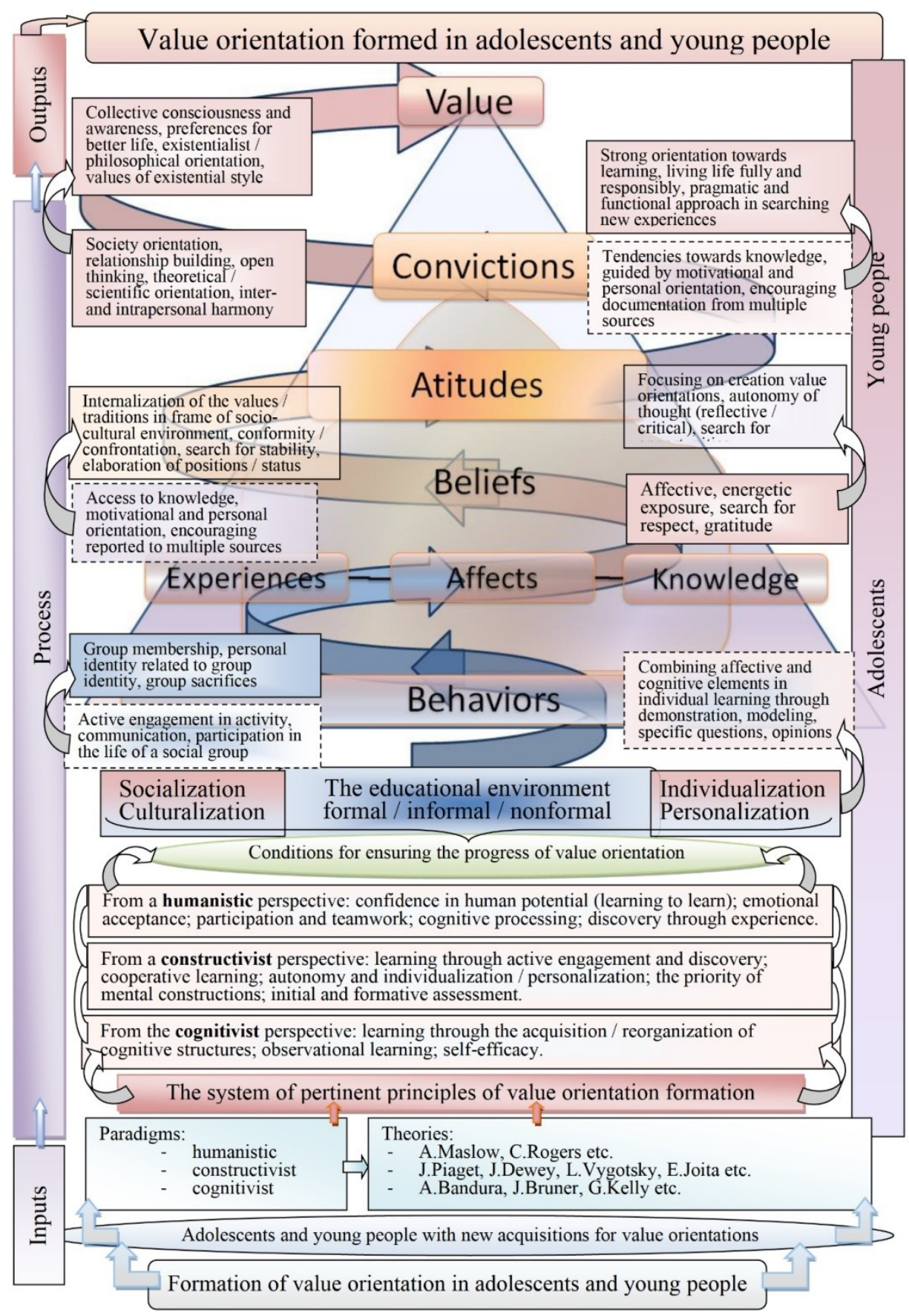

Figure 2. Pedagogical model of value orientation formation in adolescents and young people (by D.Antoci) 
Constructivism is an essential paradigmatic direction for education. It focuses on knowledge derived from lived experiences, experienced by the subject and it is driven by the social and cultural background in which the personality is formed. Learning produces knowledge. The principles of constructivist education were: learning through active involvement and discovery; cooperative learning; autonomy and personalization / individualization; priority of mental constructions; initial and formative assessment.

Cognitivism has led to the expansion of the concept of cognition, currently being interpreted as "a set of processes by which a person acquires information about himself/herself and his/her environment and assimilates them to regulate behaviour" (Ionescu, 2006, p. 74). Cognitivism refers to the way of thinking and acquiring knowledge, involves examining learning, problem solving, intelligence, is concerned with the mechanism of changing how to solve problems in terms of ontogenesis, establishing relationships between academic results and cultural differences of subjects, etc. The principles of cognitivist education are: learning through the acquisition / reorganization of cognitive structures; observational learning; self-efficacy.

The realization of the value orientation formation process in the subjects takes place in the formal, non-formal and informal educational environment. Silistraru (2014) believes that the educational environment begins where the meeting of the educated with the educable takes place.

The environment is determined by Cristea (2006, p. 302) as a modelling factor that allows "the detection, stimulation and even amplification of genetic dispositions through formalized actions (school) and non-formal (extra didactic activities, extracurricular activities)".

At the same time, the educational environment ensures the process of socialization and culturalization of the human being. In the vision of Silistraru \& Bostan (2019, p. 64). the child's approach to culture, the integration of culture in the current and future life of the child start from the youngest age continuing throughout the life. In the family, in preschool and school institutions and in social life, the child learns cultural values, transforming them into own goods, learning to arrange own life in compliance with these.

The implementation of the above listed principles can be ensured by observing the following pedagogical conditions:

- creating a favourable psychological climate in educational contexts to promote motivation, productivity, self-expression;

- involving adolescents and young people in the design of perspective directions for personal and professional development, planning and achievement of goals; 
- encouraging subjects towards self-assessment in the teachinglearning-assessment process and involvement of cognitive resources (adaptation to the environment, learning from experience, overcoming obstacles through reflexive, critical thinking) and noncognitive ones (through affectivity, behaviours, attitudes being socially determined, developed throughout life and forming the basis for the production of values);

- promotion towards intellectual development, achievement, advancement in the context of educational environment;

- continuous evaluation of the subjects for recording progress in formation and development of the value orientations and their components;

- challenging the subjects in organized contexts for capitalization of personal contents, mobilization and achievement of the goals of prosperity, well-being;

- creating educational contexts of confrontation, flexibility for development of personal positions, internalization and personalization of values in the social environment;

- organizing beneficial contexts for manifestation of the contents of the value orientations for knowledge, internalization and awareness of the wide range of values.

The principles highlighted in the studied paradigms contain common tangential aspects and constitute an effective set for the formation of value orientations by observing the conditions and strategies in the most efficient way possible, which are transposed through the previously developed value orientation formation mechanism. The process of forming value orientations takes place in a spiral, gradually involving all the constituent components during ontogenesis: behaviour, affectivity, attitude, belief, value. Each period of shaping value orientations during ontogenesis has its specificity and is influenced by individual, social, cultural and historical particularities. The process of internalizing values is of an individualized nature, while the process of externalizing value orientations is of a personalized nature.

In conceptualizing the pedagogical model of value orientation formation, we focused on the theory of the dynamics of the development of human values in the form of a spiral developed by Clare W. Graves, which was associated with the pyramid of A. Maslow. In C.W. Graves' opinion (Graves, 1996 cit. in Butters, 2013, pp. 68-69) the nature of the human being is an open system that is constantly evolving. Through his research, the scientist concluded that the human system takes place by quantum leaps from one stationary state to another and considered that the psychology of the adult is an emerging process that oscillates in a spiral, is "marked by the progressive subordination of older behavioural systems, of lower order, to 
newer systems, of higher order, as a change of existential problems of man" (ibidem). Therefore, as the prerequisites of the existence are changing, the human being manifests tendencies towards change, which takes place successively, by moving from one stage to another, reaching states of dynamic equilibrium. Focusing on a state / level of existence, the subject has a psychology specific to this state, corresponding to it are appropriate: feelings, motivations, ethics, values, neurological activity, learning systems, belief systems, management concepts, vision on the world etc. The subject can change the levels of existence to the most complex ones if the conditions of existence change. C. Graves (ibidem) is of the opinion that a person can stop at a certain level or a combination of levels. In a certain problematic situation, he / she will resort to one or another of the available coping systems.

Don Beck and Chris Cowan in collaboration with C. Graves (1996, cit. in Butters, 2013), described the essence of the theory of Spiral Dynamics, giving a number of examples. Butters (2013, p. 68) analysing the history of the development of the theory of Spiral Dynamics, considers that spirals reflect the nature of thinking, sometimes returning to the same level, but eventually progressing. Being "expansive, open, continuous and dynamic", the spiral is a model that represents both visually and functionally the development of the evolution of consciousness.

Value orientations, being integrated into consistent value systems, do not change easily. Any change involves essential transformations of the scale of preferences, reflected in behaviour, attitudes, beliefs. Attitudes are, from this point of view, more versatile and more emotionally saturated, opinions are more fluctuating as they are based on an affective and cognitive orientation limited by context. Their change can be influenced by additional knowledge of the object to which it refers, which determines its reevaluation in terms of the contents of value systems, kept relatively constant, but by reference to additional information accumulated related to the object in question.

The formation of value orientations takes place gradually, it takes place in each age period, but the final contouring is found at the age of youth. The constitution of values is initiated by internalizing the behaviours manifested by other people within groups, various events in the social environment. By children the behaviours are taken over, imitated, observed, internalized based on the approval or disapproval of adults, therefore, internalized thanks to the socialization process and then externalized giving another continuity or stopping.

Socialization is the effort of the individual to undertake behaviours noticed in other people, to be accepted as a group member, fulfilling the role 
assigned and taken over, and occupying the status assigned. Different from internalization, socialization is a process steered to the opposite direction, from the individual towards the society. Internalization of these ordinary behaviours makes the individual a social being, correspondingly, a moral being.

If the members of the social environment to which the subject belong, accept the externalized behaviours, the experimentation thereof continues, being the grounds for the development of attitudes and beliefs also formed based on experiences and knowledge acquired from childhood throughout life, developing attitudes which correlate with beliefs and manifest in different situations. New contents and modelling lead to the creation of new vectors, the spiral contouring of values. As a final point, these behaviours, attitudes, convictions give rise to the formation and gradual development of values in the personality. The shaping of values from the point of view of verticality and laterality of their contents depends on the knowledge, experiences and emotional feelings experienced by the personality. As a result of values formation in the structure of the personality, the hierarchy and the impact on the externalization of convictions, attitudes, and behaviours is already reversed: convictions, attitudes, emotional feelings and behaviours are shown under the aegis of values.

\section{Conclusions}

The approach of value orientations within the education system is brought about by the national and international trend of forming an autonomous personality able of showing independence in opinion and action, open to intercultural dialogue with regard to the assumed national and international values. The consistent and structured value orientation formation by means of organizing and developing the behaviour, knowledge, affective states, attitudes, convictions, values of the individual involved in the educational process will guarantee a progressive evolution of the personality value system.

Based on the implemented study aimed at determining the relationship of values with other components of the personality sphere of young people, we conclude the following:

- the problem of studying the values based on structural peculiarities, age, sex, social environment in adolescents and young people is up-to-date for the field of Educational Sciences;

- the performed research allowed us to identify: 
- the specificity of hierarchy of values according to the "age" criterion;

- the dynamics of the hierarchy of value orientations in adolescents and young people;

- the relationship of values with a broad range of components from the personality sphere;

- the process of forming value orientations is cyclical and is achieved through structural components: behaviours, emotional states, attitudes, convictions, values;

- the shaping of value orientations takes place gradually, adolescence and youth representing decisive stages in shaping the value system of the personality;

- the structure of the value orientations of the personality in adolescents and young people consists of latent variables, the correlation of which varies according to age and psycho-individual characteristics, while their hierarchical structure is not constant, but flexible.

Value orientations and values have a crucial role in the sphere of personality impacting the quality of life in a social, economic, political context, etc. and requiring a methodologically refined scientific approach to evaluation and training.

\section{References}

Adorno, T. (2000). Problemy filosofii morali [Problems of moral philosophy] (M. L. Khorkov, Trans.). Respublika. (Original work published 1963). http://web.krao.kg/12_filosofia/0_pdf/1.pdf

Andrei, P. (1997). Filozofia valorii [The philosophy of value] (3rd ed.). Polirom.

Antoci, D. (2018a). Educatia prin valori si pentru valori: suport de curs [Education through values and for values: course support]. Pulsul Pieței.

Antoci, D. (2018b). Valorile civice: conceptualizare, structură, evaluare [Civic values: conceptualization, structure, evaluation]. Acta et Commentationes, 2(13), 131-141. https://ibn.idsi.md/sites/default/files/imag file/131141 1.pdf

Antoci, D. (2020). Teoria ş̧ metodologia formării orientării valorice a adolescenților și tinerilor [The theory and methodology of forming the value orientation of adolescents and young people]. Print-Caro.

Botnari, V. (2014). Dezvoltarea morală: evoluție ontogenetică şi exigențe educaționale [Moral development: ontogenetic evolution and educational requirements]. In L. Şofron (Ed.), Educația morală a elevilor [Moral education of students] (pp. 24-41). Tiraspol State University.

Butters, A. M. (2013). A brief history of Spiral Dynamics. Approaching Religion, 5(2), 67-78. http://dx.doi.org/10.30664/ar.67574 
Callo, T. (2014). Pedagogia practică a atitudinilor [Practical pedagogy of attitudes]. Litera.

Council of Europe. (2018). Cadrul de referință al competențelor pentru cultură democratică. Consiliul Europei [Reference Framework of Competences for Democratic Culture published by Europe Council]. https://rm.coe.int/cdc-vol1$\angle 168097 \mathrm{e} 5 \mathrm{~d} 1$

Council of Europe. (2018). Glosarul Cadrului de referinţă al competentelor pentru cultură democratică. Consiliul Europei. [Glossary in Reference Framework of Competences for Democratic Culture published by Europe Council]. https://ccd.intercultural.ro/glosar/

Cristea, S. (2006). Educația prin valori şi pentru valori [Education through values and for values]. Didactica Pro, 1(35), 54-56.

https://ibn.idsi.md/sites/default/files/imag file/Educatia $\% 20 \mathrm{prin} \% 20 \mathrm{si}$ $\% 20$ pentru $\% 20$ valori.pdf

Cucoş, C. (1995). Pedagogie şi axiologie [Pedagogy and axiology]. Editura Didactică şi Pedagogică.

Cucoş, C. (2000). Educaţia. Dimensiuni culturale şi interculturale [Education. Cultural and intercultural dimensions]. Polirom.

Dewey, J. (1992). Fundamente pentru o stiuntă a educatiei. [Fundamentals for a science of education]. Editura Didactică şi Pedagogică.

Ewen, R. B. (2014) An introduction to theories of personality (7th ed.). Psychology Press.

Hills, M. D. (2002). Kluckhohn and Strodtbeck's Values Orientation Theory. Online Readings in Psychology and Culture, 4(4). https://doi.org/10.9707/2307$\underline{0919.1040}$

Horkheimer, M. (2002). Critical theory. Selected essays Max Horkheimer. The Continuum Publishing Company.

Ionescu, Ș. (2006). Paisprezece abordări în psihopatologie [Fourteen approaches in psychopathology] Polirom.

Karpushina, L. V., \& Kaptsov, A. B. (2007). Structura lichnostnyh tsennostei [The structure of personal values]. Vestnik Samarskoi gumanitarnoy akademii [Bulletin of Samara Humanitarian Academy], 1, 61-67. https://cyberleninka.ru/article/n/struktura-lichnostnyh-tsennostey/viewer

Kon, I. S. (1989). Psibologhia rannei iunosty [Psychology of early adolescence]. Prosveschenie.

Macavei, E. (2001). Pedagogie. Teoria educatiei [Pedagogy. Theory of Education] vol. I. Aramis Print.

Maslow, A. H. (2017). Religii, valori şi experiențe de vârf [Top religions, values and experiences]. TREI.

Mudrik, A. V. (2011). Sotsializatsia cheloveka [Human socialization]. Publishing house of the Moscow Psychological and Social Institute.

Parliament of the Republic of Moldova. (2014). Codul Educatiei al Republicii Moldova nr. 152 din 17.07.2014 [Education Code of the Republic of Moldova CERM no. 152 dated by 17.07.2014]. Monitorul Oficial al Republicii Moldova, 319-324 (634). http://lex.justice.md/md/355156/ 
Pânişoară, G. (2019). Psihologia învățării: cum învață copiii şi adulții? [Learning psychology: how do children and adults learn?]. Polirom.

Pâslaru, V. (2006). Valoare şi educație axiologică: definiție şi structurare [Axiological value and education: definition and structuring]. Didactica Pro, 1(35), 3-10. https://ibn.idsi.md/sites/default/files/imag file/Valoare $\% 20$ si $\% 20$ educati e $\% 20$ axiologica $\% 20$ definitie $\% 20$ si $\% 20$ structurare.pdf

Râmbu, N. (1997). Filosofia valorilor [Philosophy of values]. Editura Didactică şi Pedagogică

Rybak, O. S. (2018). Value orientations of people leaning toward different types of culture. Journal of Education Culture and Society, 2, 11-23. http://dx.doi.org/10.15503/jecs20182.11.23

Silistraru, N. (2006). Valori ale educatiei moderne [Values of modern education]. Institutul de Ştiințe ale Educaţiei.

Silistraru, N. (2014). Mediul etnic şi social al educatului [The ethnic and social environment of the educated]. In V. Gutu (Ed.), Materialele Conferintei științifice internaționale "Învățământul postmodern : eficienţă şi funcţionalitate", 15 noiembrie, 2013 [Proceedings of the International Scientific Conference "Postmodern Education: Efficiency and Functionality", November 15, 2013] (pp. 58-62). CEP USM.

Silistraru, N., \& Bostan, G. (2019). Mediul educaţional -factor de formare a preșcolarului ca subiect valorizator. [Educational environment - training factor of the preschool as valorisation subject]. Acta et Commentationes (Ştiinte ale Educatiei), 11(2), 60-68. https://revista.ust.md/index.php/acta educatie/article/view/201/202

Tomin, V. V. (2017). Tsennosti i tsennostnyye oriyentatsii kak osnova krosskul'turnogo vzaimodeystviya studentov [Values and value orientations as the basis for cross-cultural interaction of students]. Vektor nauki Tol'yattinskogo gosudarstvennogo universiteta. Seriya: Pedagogika, psikhologiya, 2(29), 59-64. https://doi.org/10.18323/2221-5662-2017-2-59-64

Vianu, T. (1998). Filosofia culturii si teoria valorilor [Philosophy of culture and theory of values]. NEMIRA.

Voicu, B. (2008). Valorile şi sociologia valorilor [Values and sociology of values]. Sociologie [Sociology], 249-294. http://www.iccv.ro/valori/texte/valoricvb, $\% 20 \mathrm{v} 4 . \mathrm{pdf}$ 